\title{
Celbiochemie van trombose en hemostase
}

Citation for published version (APA):

Heemskerk, J. W. M. (2010). Celbiochemie van trombose en hemostase: de context van ervaren. Maastricht University. https://doi.org/10.26481/spe.20101203jh

Document status and date:

Published: 03/12/2010

DOI:

10.26481/spe.20101203jh

Document Version:

Publisher's PDF, also known as Version of record

\section{Please check the document version of this publication:}

- A submitted manuscript is the version of the article upon submission and before peer-review. There can be important differences between the submitted version and the official published version of record.

People interested in the research are advised to contact the author for the final version of the publication, or visit the DOI to the publisher's website.

- The final author version and the galley proof are versions of the publication after peer review.

- The final published version features the final layout of the paper including the volume, issue and page numbers.

Link to publication

\footnotetext{
General rights rights.

- You may freely distribute the URL identifying the publication in the public portal. please follow below link for the End User Agreement:

www.umlib.nl/taverne-license

Take down policy

If you believe that this document breaches copyright please contact us at:

repository@maastrichtuniversity.nl

providing details and we will investigate your claim.
}

Copyright and moral rights for the publications made accessible in the public portal are retained by the authors and/or other copyright owners and it is a condition of accessing publications that users recognise and abide by the legal requirements associated with these

- Users may download and print one copy of any publication from the public portal for the purpose of private study or research.

- You may not further distribute the material or use it for any profit-making activity or commercial gain

If the publication is distributed under the terms of Article $25 \mathrm{fa}$ of the Dutch Copyright Act, indicated by the "Taverne" license above, 


\section{Maastricht University}

dr. Johan W.M. Heemskerk

Faculty of Health, Medicine and Life Sciences

Celbiochemie van trombose en hemostase: de trombus

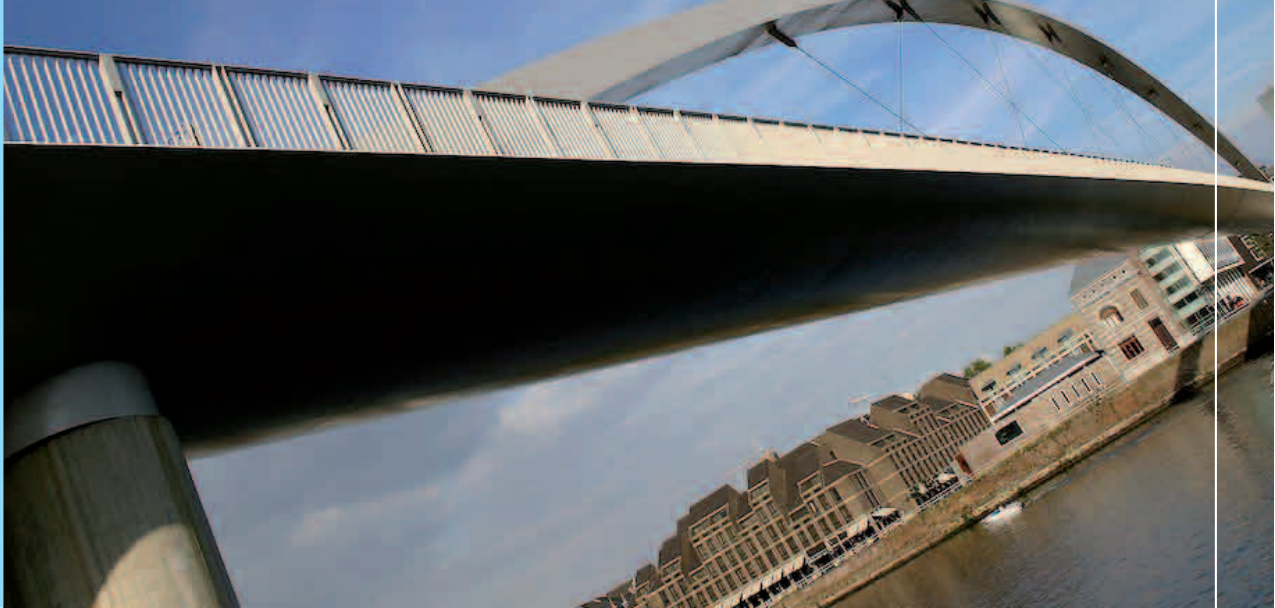


Celbiochemie van trombose en hemostase: de trombus 


\section{Colofon}

Ontwerp en print: Océ Business Services, Maastricht

ISBN: 978-90-5681-352-9

NUR: 915

Alle rechten voorbehouden. Niets uit deze uitgave mag worden verveelvoudigd, opgeslagen in een geautomatiseerd gegevensbestand of openbaar gemaakt worden, zonder voorafgaande schriftelijke toestemming van de auteur of uitgever. 


\title{
Celbiochemie van trombose en hemostase: de trombus
}

\author{
Cell biochemistry of thrombosis and \\ haemostasis: the thrombus
}

\section{Rede}

uitgesproken bij de aanvaarding van het ambt van hoogleraar in de Celbiochemie van Trombose en Hemostase aan de Faculty of Health, Medicine and Life Sciences van de Universiteit Maastricht

vanwege de Stichting Wetenschapsbeoefening Universiteit Maastricht

Maastricht, 3 december 2010

dr. Johan W.M. Heemskerk 
Voor Marly, Stella, Toine

What Remains to be Discovered, John Maddox, 1998 
Mijnheer de Rector Magnificus,

Mijnheer de Decaan,

Zeer gewaardeerde toehoorders,

Welkom iedereen! Het verheugt mij dat u met zovelen naar deze openbare les over de celbiochemie van trombose en hemostase bent gekomen. Ik heb deze taak enerzijds letterlijk opgevat, en ben plan $u$ iets te leren over het één en ander, en anderzijds wil ik mijn visie geven op de toekomst van dit onderzoeksveld. In de les van vanmiddag behandel ik daartoe een viertal thema's waarin de trombus centraal staat, met nu en dan een terugblik naar het verleden.

\section{Introduction}

Toen ik indertijd promovendus was bij de vakgroep Plantkunde van de Radboud Universiteit Nijmegen, werd ik in het bijzonder gegrepen door de fysiologische betekenis van de vele scheikundige processen die in een levende cel plaatsvinden. Indertijd was dat de plantencel, 1 en nu is dat de animale cel, maar mijn fascinatie voor de vertaling van de celbiochemie naar de functies van cellen, weefsels en organen is gebleven. Vooral ook omdat, zelfs met de huidige kennis van het menselijke genoom, er nog zo ontzettend veel is dat we niet weten en dat nog ontdekt moet worden.

Staat u mij nu toe, gezien de aanwezigheid van niet-Nederlands sprekende aanwezigen, kort over te schakelen naar de Engelse taal.

Welcome, dear friends and colleagues from abroad at this public lecture at the University of Maastricht! Your presence proves again that this university and also this city, located at the periphery of the Netherlands, flourishes because of its many foreign contacts and influences. I will speak here about the research of today, but also about the city of yesterday. In particular, the French tradition of instrument building in the $19^{\text {th }}$ century, which not only contributes to the appeal of this city of today, but also at some extent will determine this university's new activities. Let me give an example. 


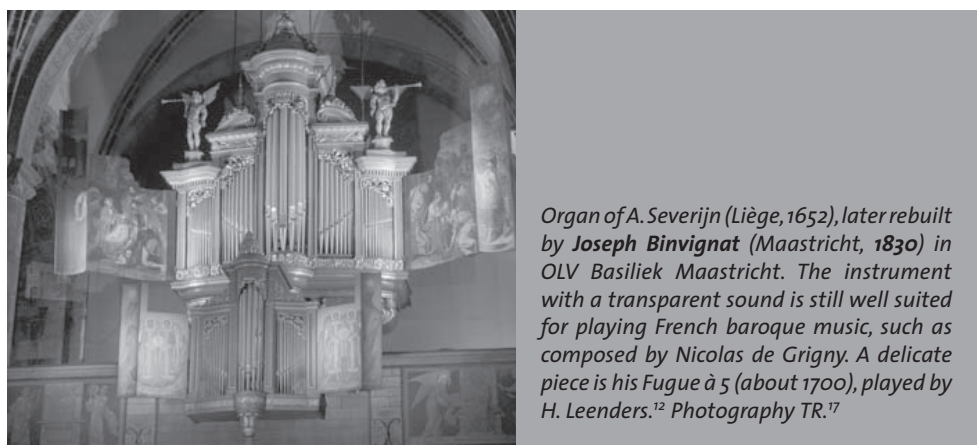

In 1830, the organ builder Joseph Binvignat from Maastricht reconstructed this old instrument, retaining its typical French/Walloon sound.

Laat ons eens onder de loep nemen het meest beweeglijke orgaan van het menselijk lichaam, het bloed, tevens het orgaan dat bestudeerd wordt in het onderzoeksveld trombose en hemostase. Dankzij een onafgebroken snelle stroming, opgewekt door het kloppende hart, worden andere organen door het bloed voorzien van voedingsstoffen en zuurstof. In geval van scheuring van een bloedvat vinden er reacties plaats, die de vloeibaarheid van het bloed plots verlagen en daarmee zorgen voor stolling. Deze hemostase is een uitermate belangrijk proces, want indien onvoldoende, treden er bloedingen op die zelfs levensbedreigend kunnen zijn. Een soortgelijk proces kan echter ook optreden in intacte maar vaak zieke bloedvaten: men spreekt van een intravasculaire trombus. Een trombus al dan niet afsluitend in de slagaders of arteriën van bijvoorbeeld het hart zorgt voor arteriële trombose, terwijl een trombus in de aders of venen leidt tot veneuze trombose. Als we de samenstelling van het bloed in ogenschouw nemen - met de grootste volumina ingenomen door het bloedplasma en de rode bloedcellen, en maar kleine volumina voor de witte bloedcellen en bloedplaatjes -, dan zijn vooral de compartimenten plasma en plaatjes betrokken bij de vorming van een fibrinestolsel en een trombus. Dit zijn compartimenten die respectievelijk een heel groot (54\%) en klein (0.4\%) volumedeel van het bloed in beslag nemen (Figuur 1). Recente proteomics analysen laten zien dat beide compartimenten onverwacht complex van samenstelling zijn met $>4400$ en $>3000$ soorten eiwitten. Van de meeste van deze eiwitten is de functie onbekend, en daarin wil mijn onderzoek opheldering brengen. 


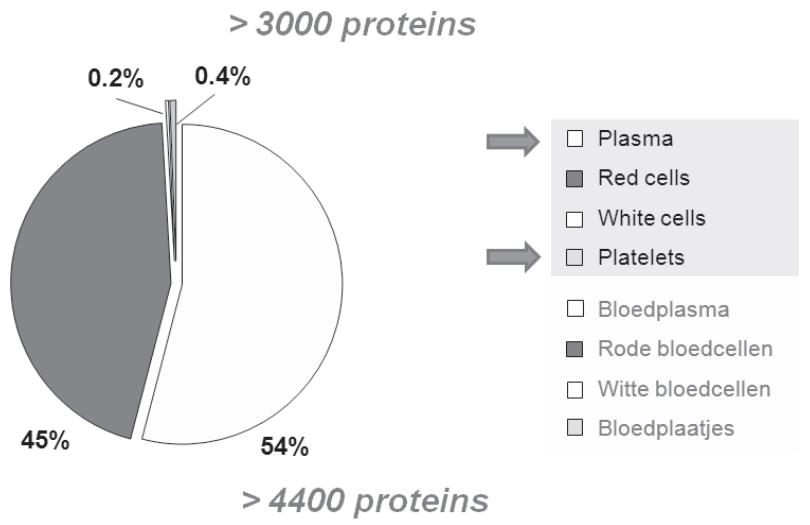

Figuur 1. Samenstelling van het bloed met relatieve volumina (\%) van de compartimenten.

Zoals vermeld door de Nederlandse Hartstichting, zijn hart- en vaatziekten niet meer doodsoorzaak nummer 1 in Nederland. Dat zijn nu kwaadaardige tumoren oftewel kanker.2 Toch overlijdt gemiddeld nog één op de drie Nederlanders aan hartvaatziekte, en neemt de kans daarop toe met de leeftijd bij zowel mannen als vrouwen. Andere cijfers laten zien dat er in Nederland nog steeds meer dan 1 miljoen mensen lijden aan hartvaatziekte, van wie er zo'n 190.000 leven met de gevolgen van een beroerte. Deze ziekte blijft dus een enorm probleem voor mens en maatschappij. Anderzijds hebben we al veel bereikt in de bestrijding; denk daarbij aan de vooruitgang in detectie-mogelijkheden (bijvoorbeeld het thuis opnemen van hartfilmpjes) en in medische technologie (pacemakers, dotteren en het plaatsen van stents). Tevens is de medicatie aanzienlijk verbeterd, maar naar mijn mening is daar nog veel extra winst te behalen. Wetenschappelijk onderzoek naar preventie en behandeling blijft daarom onverminderd noodzakelijk.

Specifieke hartproblemen buiten beschouwing gelaten, treden de grote problemen bij hartvaatziekte vaak pas op bij intravasculaire trombusvorming. Dat is bijvoorbeeld het geval bij een trombosebeen, een hartinfarct door een verstopte kransslagader of een beroerte ontstaan door een verstopte hals-arterie. De onderliggende oorzaken kunnen zijn een abnormale doorbloeding van het bloedvat of een zieke vaatwand, zoals bij atherosclerose. Een ontstane trombus sluit het bloedvat geheel of gedeeltelijk af, waardoor het omringende weefsel wordt aangetast en zelfs afsterft. Vanouds wordt een veneuze trombus aangeduid als een 
rode (in werkelijkheid bijna zwarte) trombus met daarin veel fibrine en rode bloedcellen. Anderzijds wordt een arteriële trombus omschreven als wit met daarin herkenbare structuren van geaggregeerde bloedplaatjes. Vaak echter is dit onderscheid helemaal niet zo duidelijk: een rode trombus kan witte gebieden hebben en andersom. Op grond hiervan postuleer ik dat de typische veneuze en arteriële trombus in feite twee uiterste representanten zijn van een heel continuüm met allerlei tussenvormen.

Bekend is dat we het risico op trombose zelf kunnen verlagen door lifestyle aanpassingen, waarbij ik noem gezonde voeding, niet roken en veel bewegen. Naar mijn mening kunnen deze aanpassingen slechts een gedeeltelijk preventief effect hebben, alleen al gezien de leeftijdsafhankelijke verhoogde kans op hartvaatziekte. Wanneer er eenmaal een veneuze of arteriële trombose is opgetreden, dan zijn de mogelijkheden voor medicatie nog steeds beperkt, vaak nog met een bloedingsrisico als bijwerking. Weliswaar komen er in de nabije toekomst nieuwe geneesmiddelen bij, nu in klinische trials, maar die werken soortgelijk als de oude medicamenten. Het is dan taak van de celbiochemie om nieuwe aangrijpingspunten voor medicijnen te vinden, die op een andere wijze inwerken op dit proces en daarmee hopelijk beter zijn.

\section{Theme 1: platelets and coagulation}

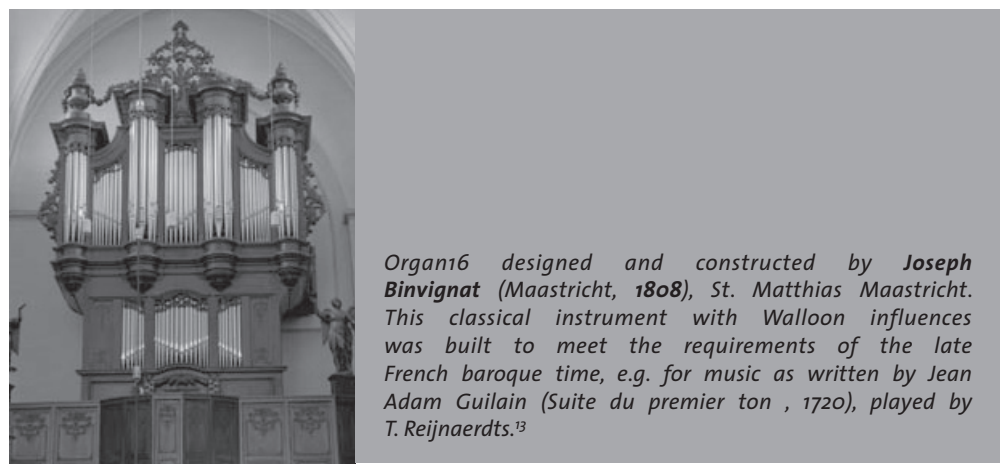

In 1808 , the same Joseph Binvignat had already built this classical master piece. 
leder van $u$ heeft vast wel eens een onderzoek naar trombusvorming uitgevoerd. $U$ hebt dan waargenomen dat er bij een neusbloeding eerst vloeibaar bloed uit de wond stroomt, dat het bloed vervolgens kleveriger wordt, en na enige minuten verandert in een bijna zwarte massa van gestold materiaal. Dit is één van de manieren van trombusvorming. De vraag wat zich precies afspeelt tijdens dit proces is ook de vraag die wij ons elke dag in het lab stellen. Dat bloedplaatjes hierbij belangrijk zijn, kunt $u$ weten doordat een aspirientje de bloedingstijd verlengt; dat de trombinevorming belangrijk is mag bekend zijn, omdat juist dit proces onderdrukt wordt door zogenaamde bloedverdunners. Aan de vakgroep Biochemie van de Universiteit van Maastricht wordt al van voor de jaren 80 onderzoek uitgevoerd naar de interacties tussen deze processen.3.4 Daarbij is aangetoond dat op het oppervlak van geactiveerde bloedplaatjes de vorming van trombine plaats vindt, en dat dit trombine omgekeerd weer in staat is om de bloedplaatjes te activeren. Dit bijzonder succesvolle onderzoek van prof. Coenraad Hemker, prof. Robert Zwaal en hun medewerkers heeft daarmee laten zien dat de bloedcompartimenten op ingenieuze wijze met elkaar communiceren (Figuur 2). Het heeft verder methodes opgeleverd om de trombinegeneratie in bloedplasma automatisch te meten, welke steeds meer gebruikt worden voor de diagnostiek van de bloedstolling. Echter gevoelige meettechnieken, waarin de rol van zowel bloedplaatjes als trombine bij de stolsel- en trombusvorming bepaald kan worden, bestaan er nog niet. Daarop wil ik mijn onderzoek in de toekomst gaan richten.

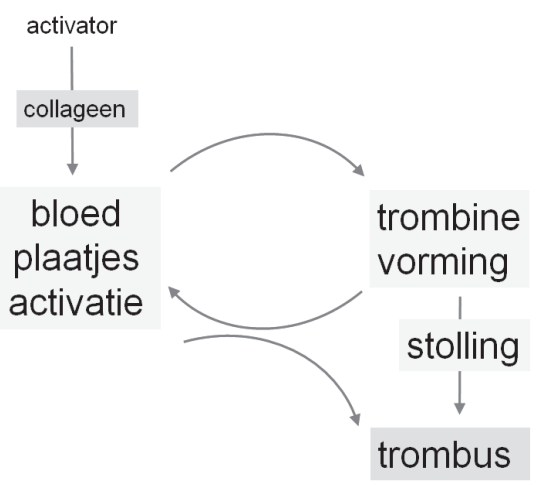

Figuur 2. Interacties tussen bloedplaatjesactivatie en trombinevorming in plasma. 


\section{Human blood}
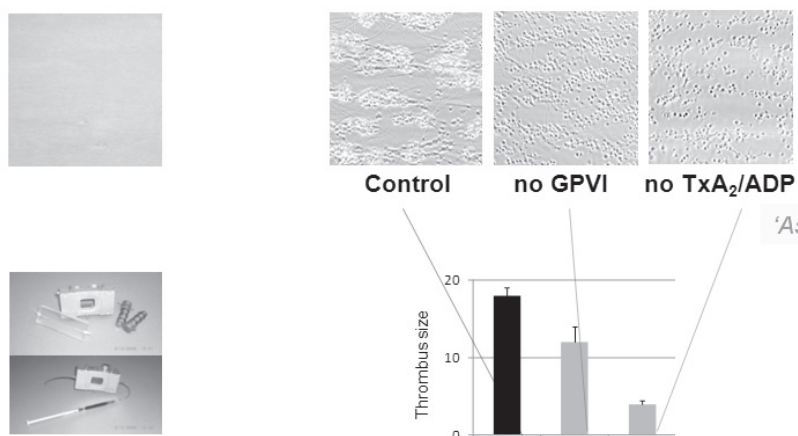

flowkamer

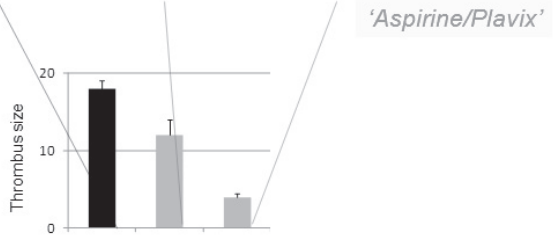

Figuur 3. Rol van de GPVI receptor op bloedplaatjes in de trombusvorming, zoals gemeten met behulp van flowkamers

Een aantrekkelijke methode daarvoor wordt al enige jaren in ons lab gebruikt. Door bloed onder gecontroleerde condities van stolling te laten stromen over een collageenoppervlak in een kleine, transparante flowkamer, ontstaat er geleidelijk een trombus opgebouwd uit geactiveerde bloedplaatjes.

Graag neem ik u mee naar een paar belangrijke resultaten, verkregen met deze flowkamer-technologie. Allereerst een onderzoek naar de rol van de receptor glycoprotein VI (GPVI), waarmee bloedplaatjes aan collageen kunnen binden. ${ }^{5}$ In samenwerking met prof. Richard Farndale uit Cambridge hebben wij laten zien dat in humaan bloed blokkade van de GPVI receptor zorgt voor uitschakeling van de vorming van trombi (Figuur 3). Eenzelfde onderdrukking van de trombusvorming zien we als we aan het bloed farmaca toedienen, die de werking van TxA $\mathrm{A}_{2}$ en ADP onderdrukken.4 Dit zijn stoffen met een soortgelijke werking als de door veel patiënten gebruikte combinatie van Aspirine en Plavix. Inmiddels kennen we steeds meer genetische mutaties van niet alleen de GPVI receptor maar ook van veel andere plaatjesreceptoren, die in sommige mensen wèl en in andere mensen niet voorkomen, en die bepalend zijn voor de activiteit van de bloedplaatjes. De grote verschillen die wij zien in de mate van trombusvorming tussen verschillende proefpersonen zouden heel goed door deze mutaties verklaard kunnen worden. Hier is nog veel werk aan de winkel. 
Als tweede voorbeeld beschrijf ik hoe ook de bloedstolling bijdraagt aan trombusvorming onder stromingscondities. Hiervoor wordt bloed gebruikt waarin we de stolling bewust aanzwengelen. In een recent onderzoek wilden we meer te weten komen over de rol van twee relatief weinig bestudeerde factoren, betrokken bij de initiatie van de bloedstolling, namelijk factor XI en XII. Met behulp van flowkamers konden wij aantonen dat de afwezigheid van ofwel factor XI ofwel factor XII in muizenbloed resulteerde in een normaal ontstaan van plaatjestrombi, maar in een nagenoeg uitgeschakelde vorming daarna van een massief fibrinestolsel. ${ }^{6}$ Dit duidt op een protrombotische rol van beide factoren, hetgeen ook in andere trombosemodellen bevestigd kon worden. Niet onbelangrijk is dat patiënten met factor XI deficiëntie een verhoogde bloedingsneiging hebben, maar patiënten met factor XII deficiëntie niet. Dit biedt goede perspectieven voor het testen van factor XII remmers als mogelijke antitrombotica.

Inmiddels kennen we nogal wat eiwitten en factoren die bijdragen aan dit proces van trombusvorming onder flow. Het is aan de celbiochemicus om die te ordenen en met elkaar in verband te brengen middels reactieschema's. Hoe dat precies gaat is nogal saaie kost, maar een aantal moderne middelen zal ik verderop aangeven. Mijn visie is dat het proces van trombusvorming het best beschouwd kan worden als een multi-compartiment proces, waarin de verschillende bestanddelen van het bloed in interactie met elkaar de trombus opbouwen. Uiteraard zijn hierbij vooral de bloedplaatjes en het plasma betrokken, maar onze observaties wijzen daarnaast op een rol van rode en witte bloedcellen. Dit onderzoeksconcept wordt momenteel uitgewerkt.

\section{Theme 2: experimental medicine}

Back to the $19^{\text {th }}$ century. This is not only the period of renovation in organ building, but also the time where European pathologists and surgeons have made significant progress in the recognition and diagnosis of diseases.

Is er dan nog een rol van de vaatwand, zult u zich afvragen. Het ligt niet voor de hand om dit met flowkamers te onderzoeken. Ik ga daarvoor terug naar de $19^{\text {de }}$ eeuw, toen aanvankelijke werd gedacht dat een trombus aangetroffen in patiënten op de operatietafel vooral bestond 
uit pus of lichaamsafvalmateriaal. Rond 1850 wijzigde dit beeld toen de patholoog Carl von Rokitansky (in Wenen) aantoonde dat trombi in geoccludeerde bloedvaten in feite zijn samengesteld uit gestolde bloed bestanddelen (Figuur 4). 7 Toen ook liet Rudolph Virchow (in Würzburg) zien dat trombi opgewekt in levende proefdieren ook weer uiteen kunnen vallen en emboliseren.

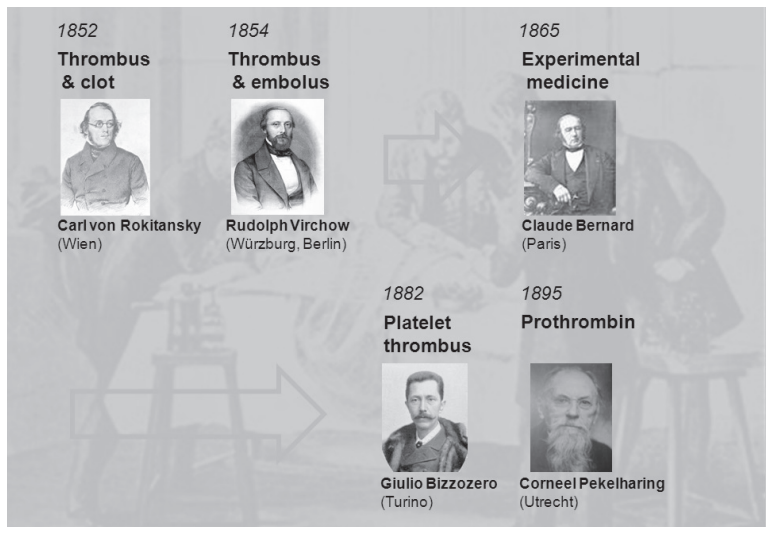

Figuur 4. Nieuwe inzichten in trombusvorming en trombose in het Europa van 1852-1895. ${ }^{7}$

In de jaren 1860 schreef de Franse arts en fysioloog Claude Bernard een baanbrekend boek over experimentele geneeskunde, dat nog steeds de moeite van het lezen waard is. Daarin rechtvaardigt hij het doen van dierexperimenteel onderzoek om de kennis van het menselijk lichaam te vergroten en om de geneeskunde te verbeteren. Om uit te leggen waarvoor de experimentele geneeskunde ook nu nog staat, citeer ik prof. Pieter Reitsma, waar deze het onderscheid beschrijft dat Bernard maakt tussen de onderzoeksvraag en de proef. 'De vraag komt meestal voort uit waarnemend klinisch onderzoek, dat wil zeggen onderzoek waarbij uitgebreid metingen worden verricht bij patiënten met bepaalde ziekteverschijnselen.'(...) 'Op grond van de vraag kunnen we dan een proef bedenken (...), waarbij de onderzoeker probeert actief in te grijpen in het ziekteproces en de gevolgen daarvan te documenteren.'

Het duurde nog enige tijd voordat de rol van bloedplaatjes in de trombusvorming werd opgehelderd.7 Dat was pas in 1882, vooral dankzij de in vivo experimenten van Giulio Bizzozero in Turijn, die trombose-modellen in proefdieren ontwikkelde die we nog steeds gebruiken. Later ook werden de eerste stollingsfactoren in plasma ontdekt. Corneel Pekelharing uit Utrecht was daarbij een voorloper met de identificatie van protrombine. 
Die oude lessen over experimentele geneeskunde zijn nog steeds toepasbaar op het moderne onderzoek naar de mechanismen van intravasculaire trombusvorming. Experimenteel onderzoek bij de mens is maar beperkt mogelijk. We doen dit wel, bijvoorbeeld in klinische interventie-trials waarin nieuwe medicijnen getest worden, maar dit onderzoek moet rekening houden met tal van veiligheidsaspecten. Anderzijds kunnen we niet voorspellen wanneer een ader in het been verstopt raakt of wanneer er een arteriële trombose in het hart ontstaat. Het is ethisch onverantwoord om actief in te grijpen door zo'n trombose op te wekken. En zelfs met de modernste scanningstechnieken lukt het maar hoogst zelden om het ontstaan van een occlusieve trombus in beeld te brengen of de trombusafbraak door medicatie te monitoren. Als gevolg van dit alles beperkt het humaan trombose-onderzoek zich meestal tot observeren en meten. Proeven met dieren, waarin experi-menteel een trombus wordt opgewekt in een bloedvat en deze dan bestudeerd, moeten daarom nog uitkomst bieden.

Vooral experimenten met muizen als proefdier zijn de laatste jaren belangrijker geworden voor de medische wetenschap. Het is dan ook verheugend dat de Universiteit Maastricht besloten heeft om te investeren in een moderne voorziening voor het huisvesten van muizen, waarmee niet alleen onderzoekers zijn geholpen, maar ook de proefdieren zelf, die een zo optimaal mogelijk onderdak zullen krijgen en infectievrij blijven. Terecht mogen in Nederland en de ons omringende landen dierproeven alleen onder strikte voorwaarden worden uitgevoerd door daartoe opgeleide en bevoegde onder-zoekers, waarbij het ongerief van het proefdier zo klein mogelijk blijft. Al het dierexperimenteel onderzoek staat onder streng toezicht van een Dier Experiment Commissie. Dit is nauwkeurig vastgelegd in de Wet op Dierproeven. Deze wetgeving moet uiteraard strikt nagevolgd worden. Waar we echter voor moeten waken is dat de vertaling van wetgeving naar huisregels niet, zoals dat in Nederland vaker gebeurt, leidt tot een overmaat van bureaucratische procedures, die soms een groter tijdsbeslag leggen op de onderzoeker en zijn team dan op het middenkader management dat die procedures uitvindt. Niet de regels moeten voorop staan, maar het welzijn van de proefdieren.

De mogelijkheden voor dierexperimenteel onderzoek naar trombusvorming zijn de laatste jaren aanmerkelijk gegroeid. Uit recent onderzoek blijkt dat er overeenkomsten, maar ook markante verschillen zijn tussen het onstaan van een veneuze trombus (hierbij wordt het bloedvat 
geheel afgesloten door een massief geheel met rode bloedcellen) en de vorming van een arteriële trombus (deze is trager, en er vindt soms geen occlusie plaats). In experimenten met prof. Steve Watson uit Birmingham kon worden aangetoond dat de bloedplatjes en de stollingsfactor protrombine op precies dezelfde plaats accumuleren in een groeiende arteriële trombus. Hier is dus inderdaad sprake van interactie tussen bloedplaatjes en stolling. Door specifiek één gen uit te schakelen en deze experimenten te herhalen, kan vervolgens effectief de rol van dit gen in het trombotisch proces bestudeerd worden.

Een voorbeeld van zo'n uit te schakelen gen is het ApoE gen. In dat geval wordt met een vetrijk dieet het cholesterolgehalte in het bloed verhoogd, en vervolgens ontwikkelen er zich atherosclerotische plaques op soortgelijke plekken als waar dat ook bij de mens gebeurt, namelijk in de aorta, de hartstreek en de hals- of carotis-arterie. Bij de mens resulteert het breken van een atherosclerotische plaque in een hart- of herseninfarct. Om dit ook bij de muis te bestuderen is er een methode ontwikkeld om een muizenplaque in de hals-arterie acuut te ruptureren met behulp van een ultrageluid probe. Uiteraard gebeurt dit onder volledige verdoving. Het resultaat van zo'n ruptuur is acute trombusvorming, die ook weer onderdrukt wordt door infusie van een Plavix-achtige stof. Naar de toekomst toe is dit plaque-ruptuurmodel zeer geschikt voor het testen van nieuwe antitrombotische medicijnen. ${ }^{6}$ Mede door het voortschrijdend inzicht in het atherosclerotisch proces, ik noem hierbij de atherosclerose-onderzoekers prof. Erik Biessen en Esther Lutgens, heeft deze onderzoekslijn een bijzonder gunstig perspectief. Ook gen-voedings interacties kunnen in dit atherotrombosemodel onderzocht worden.

\section{Theme 3: genes and flow}

Below another Binvignat instrument installed in Maastricht with a French/Walloon signature. Although it was revised and reconstructed several times, the organ retained its traditional, southern sound.

Gezien de grote overeenkomsten tussen het proces van trombusvorming bij muis en mens, hebben vele groepen onderzocht welke genen van de muis hierbij betrokken zijn. Onlangs hebben wij al de beschikbare informatie in kaart gebracht door vergelijking van alle gepubliceerde en nog niet gepubliceerde trombose-studies met knockout muizen. Enige 


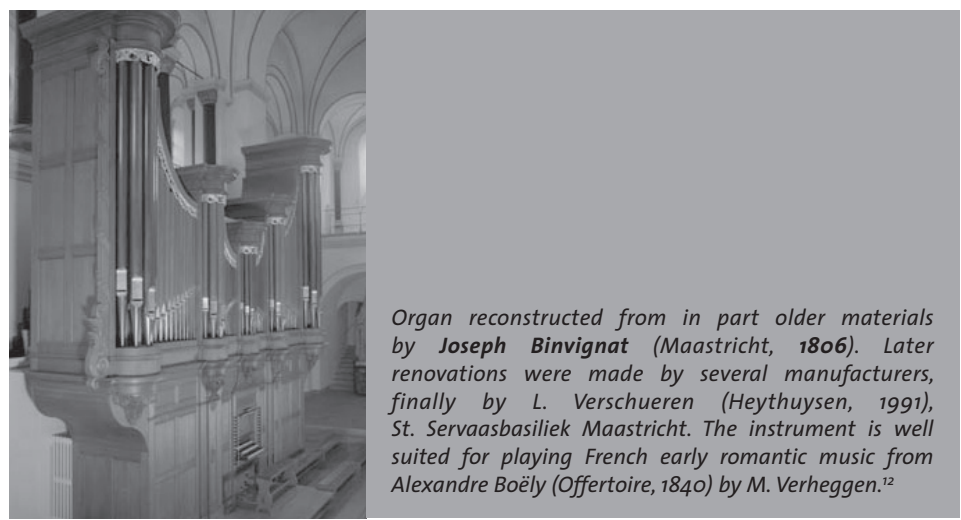

relevante resultaten wil ik hier bespreken. De vraag was, wat is het effect van het uitschakelen van een specifiek gen in de muis op de arteriële trombusvorming in vivo? Zoals weergegeven in Figuur 5 , is er vooral veel bekend van genen, die coderen voor een eiwit dat de functie van bloedplaatjes bepaalt en ook van genen die betrokken zijn bij de bloedstolling in plasma. Al met al blijken er inmiddels 73 genen voor plaatjeseiwitten te zijn (dat zijn vooral receptoreiwitten en intracellulaire signaleringseiwitten) en 12 genen voor stollingseiwitten, die een positieve bijdrage leveren aan het trombotisch proces. Daar bovenop zijn er respectievelijk 20 en 2 genen, die een negatieve rol hebben in de trombusvorming. Bij deze laatste knockouts zijn de trombi dus groter dan normaal. Over de andere bloedcompartimenten, de rode en witte bloedcellen, hebben we nog geen gegevens; en ook over de bijdrage van factoren in de vaatwand is nog maar weinig bekend. Een ander gegeven is dat de genen die coderen voor doeleiwitten van werkzame antitrombotische medicatie allemaal in de positieve categorie blijken te vallen; en dat inderdaad deze medicatie ook remmend werkt op de arteriële trombusvorming bij de muis. Samengevat levert deze exercitie belangrijke informatie op, namelijk dat het proces van trombusvorming veel complexer is dan we vroeger veronderstelden, met nu al meer dan honderd positieve en negatieve regulerende factoren van zowel de plaatjesactivering als de bloedstolling. Blijkbaar zijn al die factoren tesamen noodzakelijk om het trombotisch proces in balans houden. Als celbiochemicus denk ik dat dit nog maar het begin is (zeg maar een grote top van de ijsberg), en dat we hard verder moeten zoeken naar andere betrokken genen, om ons inzicht te completeren. Dit staat op stapel voor de komende jaren. 

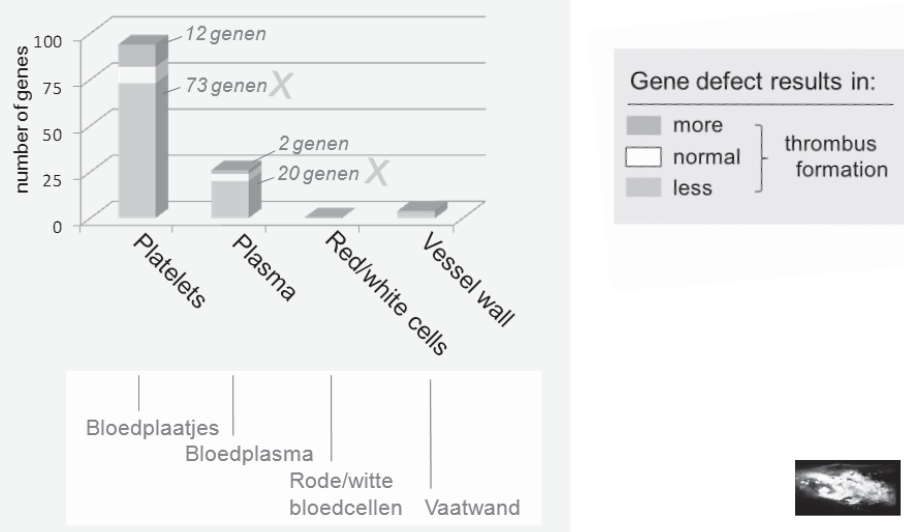

Figuur 5. Genen betrokken bij de arteriële trombusvorming.

Wat levert zo'n overzicht nog meer op? Bij 65 muizen met een verminderde trombusvorming (de groene categorie dus) is ook de bloedingsneiging gemeten. Wat dan verrassenderwijs blijkt is dat in ongeveer eenderde van de gevallen het uitschakelen van een gen niet resulteert in meer bloeding (21 van de 65 genen). Dit biedt dus een perspectief de ontwikkeling van antitrombotische middelen, die wellicht ook bij de mens geen bloedingen opleveren. Misschien vraagt $u$ zich nog af, hoeveel proefdieren er nodig zijn voor dergelijke studies. Dat zijn er relatief weinig; normalerwijze volstaat een aantal van 7-10 voor bepaling van de arteriële tromboseneiging, en eenzelfde aantal voor bepaling van de bloedingsneiging.

Hoe verhoudt de trombusvorming in het intacte proefdier zich nu tot de trombusvorming zoals die met geïsoleerd bloed gemeten wordt in flowkamers? Bij zo'n 70 typen muizen zijn deze flowkamer-metingen uitgevoerd. Ook in flowkamers hebben tientallen genen die coderen voor eiwitten betrokken bij de plaatjesactivering (44) of de bloedstolling (7) een positief regulerend effect. Het aantal genen met een negatief effect is weer beperkt. Belangrijk is dat bij meer dan 90\% van de muizen een veranderde trombusvorming in vivo gepaard gaat met een soortgelijke verandering in flowkamers. Met andere woorden, wat we meten in flowkamers is een goede afspiegeling van het trombotisch proces zoals zich dat afspeelt in het levende proefdier. Dit is onderzocht met het oogmerk van verfijning, vermindering en vervanging van proefdiergebruik. ${ }^{9}$ 
De vakgroep Biochemie heeft daarmee in ruime mate bijgedragen aan de laatste resultaten. Tot dusver zijn er middels samenwerking zo'n 44 knockouts getest, waarvan resultaten vastgelegd zijn in meer dan 40 wetenschappelijke publicatie. Door de hoeveelheid bloed nodig voor zo'n flowtest te verlagen tot een paar druppels, hopen wij binnenkort klaar te zijn voor een nog effectievere screening.

Dit onderzoek heeft onlangs een krachtig impuls gekregen voor de verdere ontwikkeling van de flowkamer-technologie middels een subsidie van het topinstituut CTMM (INCOAG project). Doel onder meer is het verkrijgen van een plaatjes- en stollingsgevoelige point-of-care test van de tromboseneiging. Een andere krachtige impuls voor het experimenteel trombose-onderzoek bieden de middelen die onder meer door universiteit, faculteit en CARIM ter beschikking gesteld zijn voor de aanschaf van geavanceerde fluorescentie-microscoopsystemen (Figuur 6). Binnen de Microscopic Imaging Unit, met prof. Mark van Zandvoort, stelt deze apparatuur ons in staat om nog sneller in de tijd en met nog hogere resolutie het proces van trombusvorming te bestuderen. Onontbeerlijk is de inbreng van prof. Tilman Hackeng voor wat betreft de ontwikkeling van nieuwe biomoleculaire markers voor de detectie van trombuscomponenten. Met de nieuwe technologie is het bijvoorbeeld mogelijk om de individuele bloedplaatjes in de trombus binnen een halsarterie te zien. Zelfs de fibrinevezels in de trombus zijn zichtbaar. Het zal duidelijk zijn dat deze microscopen tal van nieuwe mogelijkheden van onderzoek bieden.

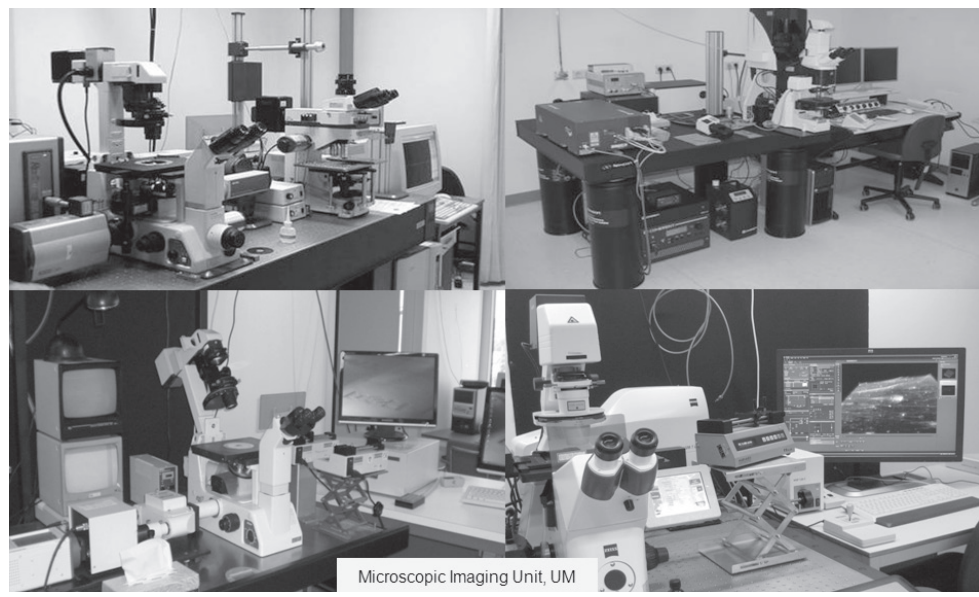

Figuur 6. Fluorescentiemicroscopie in de Microscopic Imaging Unit van UM. 


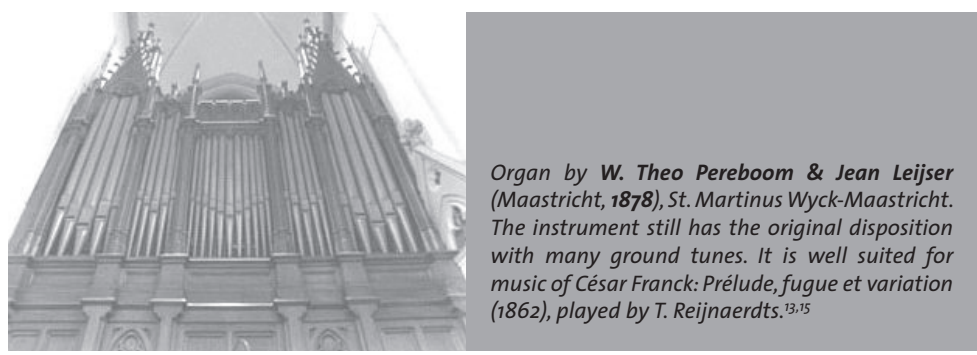

A master piece of Theo Pereboom and Jean Leijser, instrument builders in Maastricht who introduced a 19th century's French/Walloon sound concept.

\section{Theme 4: a centre of expertise}

De nog steeds zeer hoge ziektecijfers voor hart- en vaatziekten, en daarmee van atherotrombose, vergen een gerichte en gecoördineerde aanpak van alle trombose-onderzoekers en -dokters. Dit te meer daar we verwachten dat deze ziekten steeds vaker gepaard zullen gaan met welvaartsaandoeningen zoals metabool syndroom, suikerziekte en vetzucht. Het is dus essentieel dat de inzichten die de celbiochemie oplevert over nieuwe factoren, genen en regulatieprocessen van trombosen direct vertaald worden naar onderzoek, waar de patiënt baat bij heeft. Met andere woorden, de basale celbiochemie, net als de experimentele geneeskunde en de nieuw ontwikkelde testen, moeten een goede voedingsbodem kunnen vormen voor gericht translationeel onderzoek. In het CTMM samenwerkingsproject INCOAG, uitgevoerd met de Sanquin bloedbank, Philips, Synapse/Stago en de universiteiten van Leiden en Utrecht, onder leiding van prof. Hugo ten Cate, wordt daartoe momenteel een belangrijke stap gezet. Hierin wordt gewerkt aan een testbatterij voor verbeterde klinische monitoring van de stolling en de trombusvorming.

De ervaring leert dat de vertaling van basaal naar klinisch tromboseonderzoek alleen goed slaagt als er daarvoor de juiste structuren aanwezig zijn.10 Op initiatief van prof. Hugo ten Cate, dr. Karly Hamulyak en ondergetekende wordt er met steun van CARIM en het Hartvaatcentrum een Trombose Expertise Centrum (TEC) ingericht, dat een schakel moet gaan vormen tussen alle vakgroepen en afdelingen van universiteit en ziekenhuis, waarin atherosclerose, trombose en bloedingen bestudeerd worden. Het TEC kan tevens als intermediair fungeren tussen de behan- 
delende artsen, de verschillende diensten binnen en buiten het ziekhuis en de klinische onderzoekers. Het doel is daarbij tweeledig: enerzijds de patiënt zo snel en effectief mogelijk laten profiteren van de uitkomsten van het basaal en vervolgens klinisch onderzoek; en anderzijds het creëren van een sterke onderzoeksomgeving, waarin nieuwe ontwikkelingen ter preventie en behandeling van trombose maar ook van bloedingen effectief opgestart kunnen worden. Samenwerken van dit TEC met soortgelijke centra in Nederland en Duitsland ligt voor de hand.

Het TEC kan daarnaast een stimulerende rol vervullen bij het inrichten van een regionaal behandelingsplatform, waarin de patiënt optimaal kan profiteren van de kennis en ervaring van specialisten uit de hele regio, en waardoor nieuwe testen ook sneller klinisch gevalideerd en gebruikt kunnen worden. Moet dit TEC is het beste centrum van het land worden? Zeer zeker. Maar wel volgens onze criteria, en niet volgens die van een willekeurige zorgverzekeraar.

Hoe past nu de flowkamer-technologie in dit concept, vraagt u zich misschien af. We zijn nog niet zover dat dit al een klinisch toepasbare test is. Daar wordt nog aan gewerkt. Maar wat we wel al kunnen is die test uitvoeren op plaatsen waar ook de patiënt verblijft. Dit is mogelijk dankzij deze nieuw ontwikkelde kleine, maar zeer gevoelige koffermicroscoop. Hierop kan een flowkamer gemonteerd worden, en vervolgens de trombusvorming ter plekke gemeten.

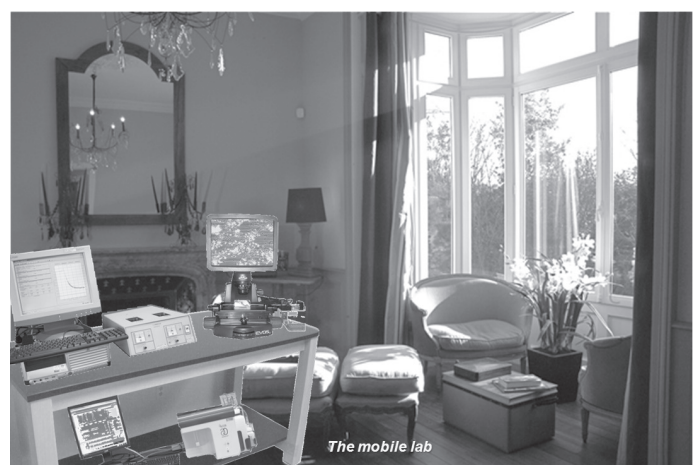

Figuur 7. Impressie van het mobiele lab. 


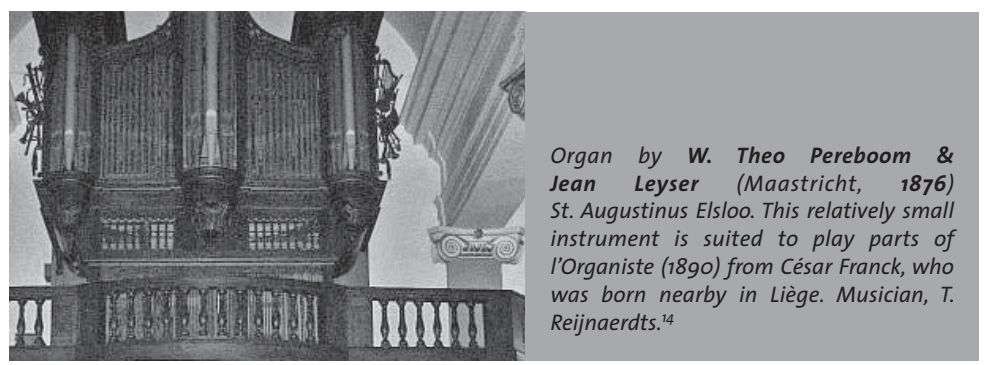

Hiermee kunnen we zelfs patiënten met een bekende bloedingszoekte of een trombose thuis bezoeken. Op deze wijze kunnen we de noodzakelijke controlestudies uitvoeren, om te bepalen bij welke gevallen van bloeding of trombose er ook bij de mens sprake is van een verlaagde danwel verhoogde trombusvorming in flowkamers. In feite zijn de plannen breder, omdat we tegelijkertijd graag willen weten in hoeverre ook andere activeringsparameters van bloedplaatjes en stolling in die patiënten veranderd zijn. Ook daarvoor bestaat er tegenwoordig kleine apparatuur, zodat idealiter zelfs in elke huiskamer een mobiel laboratorium ingericht kan worden, waarin dit alles ter plekke bepaald kan worden (Figuur 7). Ik voorzie dat deze technologie uiteindelijk op nog kleiner handzaam formaat gebracht kan worden, zodat zelfs zo'n mobiel lab niet meer nodig is.

Shown above another original, $19^{\text {th }}$ century instrument of Theo Pereboom and Jean Leyser.

\section{Finale}

In dit finale deel geef ik kort aan hoe ik de celbiochemie van de trombose en hemostase in Maastricht verder zal positioneren. Een belangrijk deel van ons onderzoek zal gericht zijn naar nieuwe factoren en regelprocessen van plaatjesactivering en bloedstolling. Het doel daarbij is om een zo compleet mogelijk inzicht te krijgen in het proces van trombusvorming en daarmee van de werkingsmechanismen van trombotische ziekten. Tegelijk zullen wij gericht onderzoek doen om te bepalen of de nieuw gevonden genen en eiwitten geschikt zijn als doel van nieuwe antitrombotische geneesmiddelen. Daarbij maken we gebruik van de reeds ontwikkelde in vivo modellen en flowkamer modellen. 
In mijn betoog ben ik niet ingegaan op de typische verschillen tussen veneuze en arteriële trombusvorming. Die zijn er zeker. Er zijn verschillende oorzaken voor het oplopen van een trombosebeen of een hersen- of hartinfarct. Ook verschilt de medicatie bij de behandeling van deze ziekten. Desalniettemin zie ik ook overeenkomsten in de factoren en processen die leiden tot veneuze en arteriële trombusvorming. Zo blijkt sinds kort dat een eiwit dat vroeger bij uitstek werd geassocieerd met arteriële trombusvorming, het glycoproteïne lb, ook belangrijk is in modellen van veneuze trombose. Dit betekent dat trombi ten dele arterieel en ten dele veneus kunnen zijn, wat ook is aangetoond. Het reeds gepostuleerde concept van een continuüm van veneus en arterieel, met daarbij een belangrijke rol van de lokale stromingscondities, zullen we in ons toekomstig onderzoek verder uitwerken.

Een ander belangrijk punt van aandacht is de nog onvoldoend begrepen rol van de vaatwand, met name de atherosclerotische vaatwand. Belangrijke open onderzoeksvragen hier zijn: hoe bepaalt deze vaatwand de opbouw van een trombus; en daarna, hoe verloopt de communicatie tussen de gevormde trombus en de daaronder liggende atherosclerotisch plaque?

Zoals u weet zijn de meeste menselijke genen inmiddels bekend. Ook worden al op steeds grotere schaal de mutaties in het DNA van patiënten en gezonde personen in kaart gebracht middels totale genomische screening. De verwachting is dat deze kennis nieuwe mogelijkheden biedt om over te gaan tot een persoons-afhankelijke geneeskunde, in het Engels aangeduid als personalized medicine. Op zeer beperkte schaal gebeurt dit nu al, bijvoorbeeld om te voorspellen of een plaatjesremmer zoals Plavix of een bloedverdunner zoals Marcoumar werkt bij bepaalde patiënten. Soortgelijke ontwikkelingen zijn er ook in het onderzoek naar de behandeling van kanker. Mutaties in het tumorweefsel bepalen soms of die tumor al dan niet reageert op een medicijn. Een toekomstig scenario is dat sommige medicamenten alleen nog voorgeschreven zullen worden na een genetische test. Dit ook al omdat de kosten van die genetische testen sterk dalen, en binnenkort veel lager zullen zijn dan die van de geneesmiddelen zelf. Voor het zover is zullen er echter snelle en eenvoudige screenings-testen moeten zijn om de werkzaamheid van medicatie in de patiënt te kunnen nagaan. Ik voorzie dat de flowkamertechnologie hiervoor goede mogelijkheden biedt, alsook voor de vroege diagnostiek van trombose. 

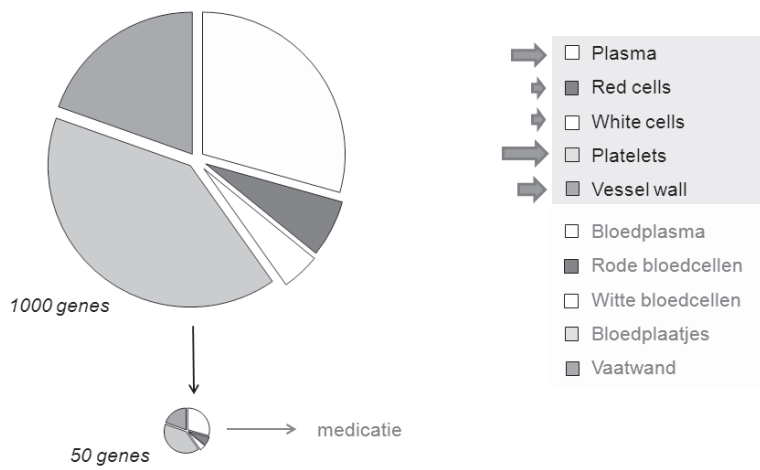

Figuur 8. Aantallen genen mogelijk betrokken bij de arteriële of veneuze trombusvorming.

Eerder heb ik al aangegeven dat proteomics analyses wijzen op het bestaan van vele duizenden eiwitten in de verschillende bloedcompartimenten, de meeste met nog onbekende functie. Mijn veronderstelling is dat er een groot aantal bekende en onbekende eiwitten betrokken is bij dit proces van trombus-vorming (Figuur 8). Voorlopig houd ik het op 1000 eiwitten en 1000 genen, die bepalend zijn voor de functies van bloedplaatjes of bloedplasma. Daarnaast zullen dit genen zijn die de vaatwandfunctie bepalen, en in mindere mate genen die tot expressie komen in de rode en witte bloedcellen. Inclusief de bekende doeleiwitten van antitrombotische medicatie ga ik er van uit dat er pakweg 50 genen en eiwitten geschikt zullen zijn als target voor medicatie.

De zoektocht naar die genen gaan wij op twee manieren aanpakken. Allereerst door een uitgebreide analyse van de trombusvorming in als het even kan 1000 knockout muizen waarin steeds een gen geïnactiveerd is. Hiervoor hebben wij samenwerkingsverbanden opgezet met instituten waar vele honderden typen muizen gehouden worden. Ten tweede door bepaling van de trombusvorming in groepen patiënten met relevante mutaties in die genen, die we bij de muis als positieve of negatieve regulator geïdentificeerd hebben. Er zijn in Nederland een aantal academische centra, waar al op grote schaal mutatieanalyses bij gezonden en patiënten worden uitgevoerd, en daarmee zullen wij samenwerken. Tevens sluiten wij aan bij internationale projecten waarin het totale genoom van grote groepen mensen sequenced wordt. Door de trombusvorming te meten in bloed van dragers en niet-dragers van bepaalde mutaties in relevante genen hopen we bij de mens de erfelijke variatie in kaart te brengen, die aanleiding geeft tot trombose of bloedingen. 
Hoe vind je nu 1000 relevante genen, zult u zich afvragen? Dat is tegenwoordig niet zo vreselijk lastig door zogenaamde systeembiologische en gen clusteranalyses. Het EMBO instituut in Heidelberg heeft bijzonder grote databases opgebouwd, waarin alle gekende biochemische reacties in ons lichaam opgenomen zijn. Als je nu de lijst met bekende genen in zo'n database stopt, en vervolgens een analyse doet op andere genen in het reactienetwerk, dan levert dat al gauw enige honderden geclusterde genen op per netwerk. Een andere vraag is, hoe vind je 50 genen die target kunnen zijn van antitrombotische medicatie; is dat wel haalbaar? Ook dat zou mee kunnen vallen. Ik breng $u$ in herinnering doodsoorzaak nummer 1 in Nederland, de kwaadaardige tumoren. Wereldwijd zijn er de laatste jaren in rap tempo vele nieuwe medicijnen ontwikkeld tegen deze tumoren.

Wat nu blijkt is dat veel van die medicijnen gericht zijn tegen dezelfde of soortgelijke genproducten als die in bloedplaatjes betrokken zijn bij de trombusvorming. Er is een lange lijst van geneesmiddelen op te stellen, die al klinisch toegepast worden als anti-tumor therapie bij bepaalde patiënten-groepen, en die mogelijk of waarschijnlijk van invloed zullen zijn op de bloedplaatjesfunctie of de bloedstolling. Dit is bij deze patiënten vaak nog niet onderzocht. Ook zulk onderzoek is een belangrijke taak voor de celbiochemie van trombose en hemostase.

The instrument below was built in 1888 by George Stahlhuth from Aachen, and later considerably revised by W.T. Pereboom and L. Verschueren. The organ, placed in the aula Tongersestraat of Maastricht University, has recently been repaired. Shown is the disposition with mixed German and French stops. It will be used for open lunch concertos.

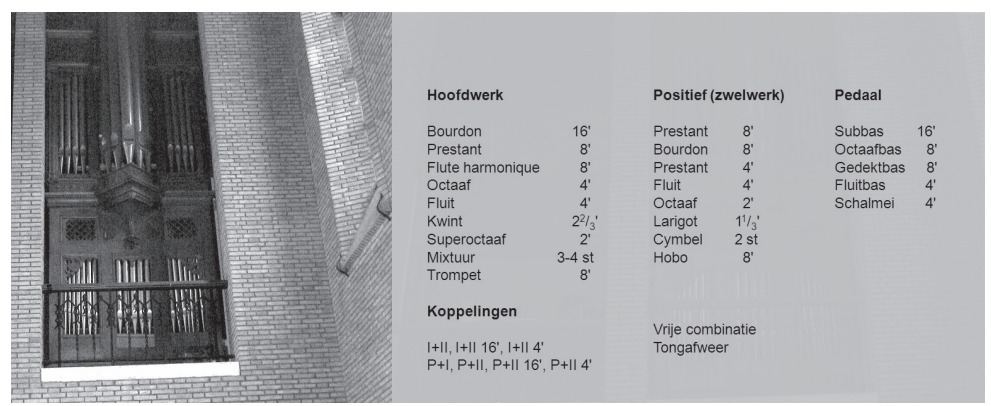




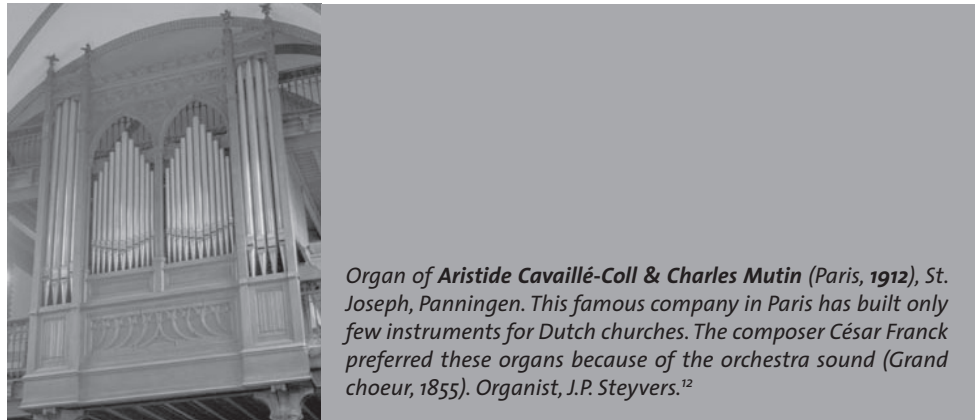

This $19^{\text {th }}$ century overview ends with an organ in the region designed by the factury of Aristide Cavaillé-Coll in Paris.

\section{Dankwoord}

Aan het eind van deze les wil ik graag enkele woorden van dank uitspreken. Ik bedank het College van Bestuur van de Universiteit Maastricht, de Decaan en het Bestuur van de Faculty of Health, Medicine and Life Sciences, alsmede de Stichting Wetenschapsbeoefening voor het in mij gestelde vertrouwen.

Zeer erkentelijk ben ik de Onderzoekschool Hart- en Vaatziekten en het Cardiovasculair Research Instituut CARIM voor de ondersteuning die ik heb mogen krijgen voor mijn onderzoek. In persoon zijn dat prof. Robert Reneman, prof. Harry Struijker Boudier, prof. Mat Daemen en het team rond directeur Rob van der Zander. Voor de steun bij het inrichten van deze leerstoel dank ik ook prof. Martin Paul en prof. Frans Ramaekers. Het Hart- en Vaatcentrum in de persoon van voorzitter Guy Peeters ben ik erkentelijk ik voor de support van het trombose-onderzoek.

Graag memoreer ik degenen, die mij indertijd op het onderzoekspad hebben gezet: mijn promotoren van de Radboud Universiteit Nijmegen, wijlen prof. Sjef Wintermans en prof. Hans-Ferdinand Linskens. Voor mij is de vakgroep Plantkunde een prima leerschool geweest voor het uitvoeren van experi-menteel biologisch onderzoek. Het doet mij deugt dat collega's uit Nijmegen hier aanwezig zijn.

Terugblikkend naar de tijd in het Biomedisch Centrum te Maastricht, bedank ik degenen die mij wegwijs hebben gemaakt in de wondere 
wereld van trombose en hemostase. Prof. Gerard Hornstra: jij hebt mij indertijd enthousiast gemaakt voor het vetzuur-, lipiden- en membraanonderzoek aan bloedcellen. De door jou uitgevoerde studies naar celfunctie en tromboseneiging zijn nog steeds actueel. ${ }^{11}$ In Maastricht is het celbiochemisch onderzoek naar trombose en hemostase op hoog niveau gebracht door prof. Robert Zwaal en zijn team met daarin dr. Edouard Bevers en dr. Paul Comfurius. Ik beschouw het als een groot voorrecht om op dit stevig fundament verder te mogen bouwen. Hooggeleerde heren Hemker en Rosing, beste Coen en Jan: jullie baanbrekend onderzoek naar de biochemie van de bloedstolling vormt de derde belangrijke pijler van mijn research. Ik waardeer het ten zeerste dat ik volledige vrijheid heb gekregen bij het inrichten van mijn onderzoek, terwijl jullie blik kritisch bleef. Mijn waardering ook voor de andere kapiteins op het slagschip Trombose en Hemostase, prof. Hugo ten Cate, Tilman Hackeng en Chris Reutelingsperger. Aan ons is het om te laten zien dat de boot uit Maastricht niet alleen de grootste is van het land, maar ook de snelste! De medewerkers van de vakgroep Biochemie dank ik voor de collegialiteit, steun en sociale inbreng.

De grote interdisciplinaire component van ons onderzoekswerk maakt dat wij afhankelijk zijn van de aanvullende kennis en inbreng vanuit andere vakgroepen, vooral binnen de instituten CARIM, NUTRIM en GROW. Helaas kan ik niet iedereen en alle vakgroepen afzonderlijk noemen, maar toch wil ik alle collega's bedanken voor de samenwerking in verleden, heden en hopelijk ook in de toekomst. Mijn vroegere collega's van de vakgroep Humane Biologie ben ik erkentelijk voor de veelvuldige onderwijscontacten.

Onze partners in het trombose-onderzoek in Nederland, België en de Duitse nabuur Länder: prof. Jan-Willem Akkerman (als pater familias), prof. Flip de Groot, prof. Marc Hoylaerts, prof. Hans Deckmyn, prof. Christian Weber en medewerkers: het verheugt mij dat ik $\mathrm{u}$ in zo grote getale mag toespreken en bedanken voor onze veelvuldige interacties. Ik zie uit naar de continuering hiervan.

To all colleagues from abroad, non-Dutch speaking: prof. Gerhard Dickneite, prof. Richard Farndale, prof. Bernhard Nieswandt, prof. Steve Watson and co-workers, I am quite pleased and feel honored with your presence today. I hope our present collaborations will continue for many more years. 
Wetenschappelijk onderzoek is een kostbare aangelegenheid, en kan niet zonder extra financiële mogelijkheden. Ik dank CTMM, de Nederlandse Hartstichting, de Landsteiner Stichting voor Bloedtransfusie Research, de Sanquin bloedbank, ZonMW en instanties in Maastricht voor hun geldelijke steun. Het verstevigen van de noodzakelijke dwarsverbanden tussen klinisch onderzoek en patiëntenzorg is als gezegd een nieuwe ontwikkeling, die de inzet en samenwerking zullen vergen van velen. Hooggeleerde ten Cate, beste Hugo, het is een uitstekend initiatief geweest om met dr. Karly Hamulyak een expertisecentrum van de grond te tillen. Ik voorzie dat dit een onmisbare schakel zal worden voor de organisatie van klinisch trombose-onderzoek in Maastricht en bij zusterinstellingen. Belangrijke contribuenten hierbij zijn prof. Marco Marcus en dr. Yvonne Hensgens.

Vele vrouwen en mannen hebben het celbiochemisch onderzoek van trombose en hemostase gemaakt tot wat het nu is. De 13 proefschriften, waarvan ik co-promotor mocht zijn, getuigen van evenzo vele enthousiaste bijdragen hieraan van promovendi, ieder met een eigen invulling. Allereerst de medewerkers van de vakgroep Humane Biologie: $\mathrm{dr}$. Wim Vuist, Cécile Nieuwenhuys en Kristof Vanschoonbeek. Jullie invloed is nog steeds merkbaar, al was het maar omdat menige vriezer nog steeds ruikt naar visolie. Dan de oud-promovendi bij de Biochemie: dr. Imke Munnix, Sandra Cauwenberghs, Saskia Schols: jullie hebben het plaatjes trombose-onderzoek mee opgebouwd. Dat geldt ook voor AIOs van buiten de gang, dr. Els den Dekker, Mirjam van Gestel, Christelle Lecut en Michelle Berny.

Andere oud-promovendi, daarmee prijs ik me gelukkig, maken nog steeds deel uit van ons onderzoeksteam. Hiervoor lanceer ik per vandaag een nieuwe afkorting, namelijk het SPT, het super-plaatjesteam. Leidinggeven aan zo'n uitdijende groep impliceert verdeling van taken en verantwoordelijkheden. Beste collega's van de SPT staf, jullie steunen en corrigeren mij, zorgen voor een goede structuur en sfeer, en begeleiden al die mensen in het lab. Ik noem dr. Edouard Bevers (als grote ervaringsdeskundige), dr. Judith Cosemans (als aanstormend talent), en dan dr. Marijke Kuijpers, Roosje van Gorp, Paola van der Meijden, Erik Westein en Jef Wolfs. Het is vrij uniek, denk ik, dat wij allemaal ook zelf nog pipetteren, en daarmee in staat zijn om de kwaliteit van de proeven te bewaken. Een speciaal woord is op zijn plaats voor Marion Feijge. Jouw ervaring in de onderzoekspraktijk kan ik nooit meer inhalen, alleen al omdat 
je een maand langer met bloedplaatjes werkt dan ik. De eer voor het SPT handwerk gaat naar onze huidige promovendi: Lina Cipolla, Susanne de Witt, Karen Gilio, Moniek Lamers, Nadine Mattheij, Reyhan Nergiz, Frauke Swieringa en Roger van Kruchten. Verder weg zijn daar ook nog Markus Lancé, Marisa Ninivaggi en Elena Vasina. En dan natuurlijk de stagiaires en studenten die nu het vak aanleren.

Beste familie, vrienden en kennissen. Ik vind het fijn dat jullie hier aanwezig zijn. Mijn zussen dank ik voor hun blijvende interesse. Mijn vader en mijn moeder - fijn dat ook jullie op de eerste rij zitten - ben ik zeer erkentelijk voor de nooit aflatende stimulansen en support. Mijn vader heeft als enige teksten aangeleverd voor deze lezing. En inderdaad, als perfessor Willem Heemskerk is hij mij al jaren geleden voorgegaan, en wel bij de oudste universiteit van Maastricht, de NUL. Verreweg de meeste dank ben ik tenslotte verschuldigd aan Toine, Stella en Marly, die er altijd zijn.

Ik heb gezegd. 


\section{Bibliografie}

1. Wintermans JFGM (1986) Symbiose en parasitisme. Afscheidscollege. Katholieke Universiteit Nijmegen, Nijmegen.

2. Rapport Hart- en vaatziekten in Nederland 2009, Nederlandse Hartstichting (2010), Den Haag.

3. Hemker HC (1999) Een bloedstollende geschiedenis. Holstlezing. Technische Universiteit Eindhoven, Eindhoven. ISBN 9038615019.

4. Rosing J (1998) Bloedstolling: een leven lang van levensbelang, Universiteit Maastricht, Maastricht.

5. Akkerman JWN (1998) Naar trombose preventie op maat. Universiteit Utrecht, Utrecht.

6. Cosemans JMEM, Kuijpers MJE, Heemskerk JWM (2010) Thrombus formation: the roles of tissue factor, platelets and flow. Hematology Education 2010; 4: 296-301. ISSN 1872 5503. Www.ehaweb.org

7. Owen CA (2001) A history of blood coagulation. Mayo Foundation for Medical Education and Research, Rochester, Minnesota, USA.

8. Reitsma P (2003) Proeven van geneeskunde. Universiteit van Amsterdam, Vossiuspers, Amsterdam. ISBN 9056293389.

9. Kabinetsvisie 'Alternatieven voor dierproeven' 4 juni 2008. Nederlandse Regering, Den Haag.

10. Ten Cate H (2003) Grenzen vervagen: hemostase in beweging, Universiteit Maastricht, Unigraphic, Maastricht. ISBN 9056811673.

11. Hornstra G (2003) Vetzuren, essentieel van de wieg tot het graf, Universiteit Maastricht, Maastricht.

\section{Discografie}

12. Historische Orgels in Limburg. Stichting S.O.L. (2003). www.stichting-sol.nl

13. Monumentale Stadsorgels in Maastricht (2003) TRA Productions Ton Reinaerdts, Maastricht.

14. César Franck: Trois Chorales, I'Organiste (2005) TRA Productions Ton Reijnaerdts, Maastricht

15. Pereboom \& Leijser, Orgelmakers te Maastricht (1997) F. Jespers, H. van Loo, T. Reijnaerdts. www.stichting-sol.nl

\section{Fotografie}

16. Foto omslag: Henri Spronk

17. Foto orgels: htpp://tonreijnaerdtsorganpage.nl 
